\title{
A Ratio Method for Calculating Stem Volume to Variable Merchantable Limits, and Associated Taper Equations
}

by

\author{
I.S. Alemdag ${ }^{1}$
}

\begin{abstract}
One method for estimating the volume of the merchantable portion of a tree stem is the volume ratio method. In this study the ratio used with this method was derived from another ratio expressed as groundto-limit volume to total stem volume. Because of the latter ratio's strong correlation with the ratio of merchantable top diameter/breast height diameter and merchantable height/total tree height, several mathematical models were formed employing these variables for its estimation for red pine (Pinus resinosa Ait.) and sugar maple (Acer saccharum Marsh.). Among the models that were tested, the best for each variable was chosen by assessing its adequacy by the statistical measures of fit index and standard error of estimate. When checked against an independent set of data, these best models performed satisfactorily, with small overall biases. Furthermore, taper equations were derived from these ground-to-limit volume ratio equations.
\end{abstract}

\section{Résumé}

II est possible d'estimer le volume de la partie marchande d'une tige par rapport au volume de l'arbre. Nous avons employé dans la présente étude un rapport tiré d'un autre rapport exprimé sous la forme suivante: volume du collet à la limite marchande/volume total de la tige. Comme il existe une forte corrélation entre ce dernier rapport et les rapports diamètre au fin bout de la tige/diamètre à hauteur de poitrine et hauteur marchande/hauteur totale de l'arbre, plusieurs modèles mathématiques ont été construits à l'aide de ces variables pour l'estimation du rapport pour le pin rouge (Pinus resinosa Ait.) et l'érable à sucre (Acer saccharum Marsh.). Nous avons contrôlé ces modèles et déterminé celui qui était le meilleur pour chaque variable d'après le coefficient d'ajustement et l'écarttype d'estimation. Les modèles retenus, appliqués à un ensemble indépendant de données, ont donné des résultats satisfaisants, avec un faible biais global. De plus des équations de défilement ont été tirées de ces équations du rapport volume du collet à la limite marchande/volume total de la tige.

\section{Introduction}

Total tree-stem volume, when expressed on a unit area basis, is a good indicator of the existing amount of timber in a given region. When related to the age of stands it provides some idea of the growing capacity and productivity of the land. Growth and yield studies are usually based on total stem volume; however, this measure does not provide information on the amount of wood for a given utilization standard. For example, the quantity of sawtimber or pulpwood available from the land cannot be ascertained. The sawtimber portion of the stem or any product to a utilization standard is called merchantable wood, and the profitability of many forest product manufacturing companies is based on a reliable estimate of its volume. There are a few methods of obtaining this estimate. The principal purpose of this study is to focus on one of them - the ratio method - and to develop a system for preparing merchantability prediction equations, using a softwood species, red pine (Pinus resinosa Ait.) and a hardwood species, sugar maple (Acer saccharum Marsh.) from Ontario as examples. Secondarily, its intention is to

derive some taper equations by employing these merchantability factors. The system developed here will be used later for several other Ontario species.

Calculating the merchantable volume content of a stem can be done either directly or indirectly. Direct estimates include: (1) measuring diameters at different locations on a stem, either felled or standing, and performing direct calculations of volume by sections between the two specified points of interest on the stem, and (2) ocular estimations based on past experience. Indirect estimates employ one of the following methods: (1) construction of taper curves, (2) development of volume equations to a fixed top diameter or height and, (3) establishment of merchantable volume/ stem volume ratios to a variable top diameter or height. The direct estimates are self-explanatory. The indirect volume estimation systems require developing a mathematical formula to be used with the actual data.

Taper curves are expressions of the stem profile in terms of diameters and heights along the bole. Using this stem profile, one can calculate the volume of any segment of a bole as a solid of revolution by integrating the taper function. This subject has been studied at length; see, for example, Behre (1923 and 1927), Anonymous (1930), Stiell and Von Althen 
(1964), Bruce et al. (1968), Kozak et al. (1969), Bennett and Swindel (1972), Demaerschalk (1972 and 1973), Ormerod (1973), Goulding and Murray (1976), Demaerschalk and Kozak (1977), Liu and Keister (1978), Clutter (1980), Liu (1980), Alemdag (1983), Amidon (1984), Biging (1984), and James and Kozak (1984). Merchantable volume equations, restricted to specific top diameters and based on breast height diameter and total tree height, were constructed independently for each top diameter by Bennett et al. (1959), Romancier (1961), and Gingrich (1962). Some recent work with the merchantable volume/stem volume ratio approach for a variable top diameter or height include Honer (1964 and 1965), Burkhart (1977), Brister et al. (1980), Cao and Burkhart (1980), Cao et al. (1980), Monserud (1981), Schlaegel (1981), Van Deusen et al. (1981 and 1982), Matney and Sullivan (1982), Reed and Green (1984), Green and Reed (1985), and Reed and Byrne (1985). Alemdag's ratio method (1982), in conjunction with the biomass of the merchantable portion of a stem, falls into the same category.

The ratio method estimates the ratio of merchantable volume to total stem volume, and employs merchantable top diameter or merchantable height as an independent variable together with breast height diameter, total tree height, and in some cases stump height. In other words, when developed, equations for merchantable volume ratios or merchantable volume conversion factors are used for flexible top diameters or variable heights. The merchantable volume calculated is the product of these factors and the total stem volume, either obtained by direct measurement or estimated from a volume table or function. Stump volume may have to be taken into consideration if stump height was not used as an independent variable in the ratio equation. The volume of a segment of a tree stem can also be calculated in this manner using these ratios, once for the upper and once for the lower diameter on the trunk

\section{Notation}

A list of notations used in the text is given below and illustrated in Figure 1. Throughout this report diameters are expressed in centimetres; heights (including stump height) in metres; and volumes in cubic metres, inside bark, and regardless of decay and defect. Hence:

$\mathrm{D}=$ breast height diameter at $1.30 \mathrm{~m}$, outside bark

$\mathrm{d}=$ merchantable top diameter, inside Bark

$\mathrm{H}=$ total tree height

$h=$ merchantable height (height from ground level to a specified utilization limit)

hs = stump height

VT = total stem volume from ground level to the tip of the tree

$\mathrm{VM}=$ merchantable volume $($ volume from stump height to a specified utilization limit)

VS30 $=$ stump volume at $0.30 \mathrm{~m}$ stump height

VS = stump volume at a given stump height

$V P=$ top volume above a given merchantable top diameter, or, above a given merchantable height

$\mathrm{VL}$ = ground-to-limit volume (volume from ground level to a specified utilization limit)

$f=$ breast-height stem form-factor (cylindrical form factor)

\section{Data}

The data used in this study are a part of the data collected for several species of Ontario softwoods and hardwoods from natural stands on a variety of sites, ages, and cover types for

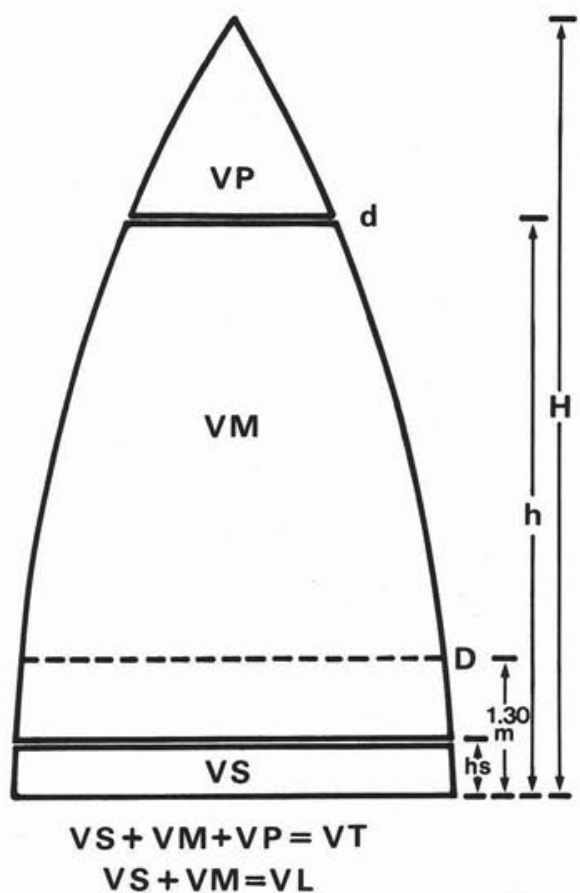

Figure 1. Components of a tree stem in reference to the concept followed in this study.

development of tree biomass relationships ${ }^{2}$. While gathering this data, the following information was also taken from every sample tree of merchantable size after it was cut at a fixed 0.30 m stump height: $\mathrm{D}$ and $\mathrm{H}$; $\mathrm{d}$ at three locations on the stem (one where diameter outside bark is $9.1 \mathrm{~cm}$, and the others at $1 / 3$ and $2 / 3$ of the height from ground level to the $9.1 \mathrm{~cm}$ point $\left.{ }^{3}\right) ; h$ at three locations on the stem where the three $d$ measurements are taken; inside- and outside-bark diameters at a stump height of $0.30 \mathrm{~m}$, at $0.80 \mathrm{~m}$ above ground, and at the bottom of the stump; and inside- and outside-bark diameters at every $2-m$ section of the stem. Later, the volume of each $1 / 3$ section of the ground-to-limit portion of stem below $9.1 \mathrm{~cm}$ of diameter was calculated independently using Smalian's formula with the measured diameters, and accumulated in succession from the lowest section upwards in the tree for each merchantable diameter or merchantable height. Volume of the top and the stump volume at $0.30 \mathrm{~m}$ stump height were also calculated. Furthermore, the ratios of these volumes to total stem volume were established. The values of the above VL/VT ratios (hereinafter called $\mathrm{K}$ wherever appropriate) theoretically range from zero to 1 . In addition to these, the ratio of merchantable top diameter to breast height diameter (also called relative diameter, $d / D$ ), and merchantable height to total tree height (also called relative height, $h / H)$, were calculated. Again, theoretically, these ratios range between zero and 1 . Smaller $d / D$ values represent a merchantable limit near the top of the tree; where $\mathrm{h} / \mathrm{H}$ is involved, the opposite is true. The statistics of the sample data used in the derivation of the equations are presented in Table 1.

2The softwood data were collected in 1978, 1981, and 1982 by Horton Forestry Services Limited of Stouffville, Ontario, and the hardwood data in 1982 and 1983 by Dendron Resoruce Surveys Limited of Ottawa, Ontario. These were under ENFOR contracts of the Canadian Forestry Service.

${ }^{3}$ Although merchantable diameter is always defined as a top diameter, the diameters along the stem at $1 / 3$ and $2 / 3$ of the merchantable height were measured in order to formulate the distribution of volume below a specified stem diameter which may serve as a merchantable volume to a variable top diameter. 
Table 1. Summary of the observed data used for model development and for checking

\begin{tabular}{|c|c|c|c|c|c|c|c|c|c|c|c|c|}
\hline \multirow{2}{*}{ Species } & \multirow{2}{*}{$\mathbf{N}^{*}$} & \multirow{2}{*}{$\mathbf{n}^{*}$} & \multicolumn{2}{|c|}{$\mathrm{D}(\mathrm{cm})$} & \multicolumn{2}{|c|}{$H(m)$} & \multicolumn{2}{|r|}{$d / D$} & \multicolumn{2}{|r|}{$\mathrm{h} / \mathrm{H}$} & \multicolumn{2}{|r|}{ VL/VT } \\
\hline & & & Mean & Range & Mean & Range & Mean & Range & Mean & Range & Mean & Range \\
\hline \multicolumn{13}{|c|}{ (a) Data for model development } \\
\hline $\begin{array}{l}\text { Red pine } \\
\text { Sugar maple }\end{array}$ & $\begin{array}{r}102 \\
93\end{array}$ & $\begin{array}{l}266 \\
238\end{array}$ & $\begin{array}{l}29.3 \\
31.1\end{array}$ & $\begin{array}{l}10.3-55.1 \\
10.0-57.8\end{array}$ & $\begin{array}{l}18.66 \\
19.75\end{array}$ & $\begin{array}{l}7.10-34.35 \\
9.86-26.41\end{array}$ & $\begin{array}{l}0.590 \\
0.596\end{array}$ & $\begin{array}{l}0.147-0.936 \\
0.133-0.925\end{array}$ & $\begin{array}{l}0.517 \\
0.448\end{array}$ & $\begin{array}{l}0.098-0.931 \\
0.076-0.838\end{array}$ & $\begin{array}{l}0.7525 \\
0.7503\end{array}$ & $\begin{array}{l}0.2286-0.9990 \\
0.2034-0.9971\end{array}$ \\
\hline \multicolumn{13}{|c|}{ (b) Data for checking } \\
\hline $\begin{array}{l}\text { Red pine } \\
\text { Sugar maple }\end{array}$ & $\begin{array}{l}44 \\
39\end{array}$ & $\begin{array}{l}44 \\
39\end{array}$ & $\begin{array}{l}30.6 \\
31.8\end{array}$ & $\begin{array}{l}11.4-54.1 \\
10.6-57.8\end{array}$ & $\begin{array}{l}18.97 \\
19.80\end{array}$ & $\begin{array}{l}8.90-34.20 \\
9.86-25.70\end{array}$ & $\begin{array}{l}0.573 \\
0.583\end{array}$ & $\begin{array}{l}0.150-0.904 \\
0.158-0.915\end{array}$ & $\begin{array}{l}0.528 \\
0.437\end{array}$ & $\begin{array}{l}0.139-0.908 \\
0.137-0.828\end{array}$ & $\begin{array}{l}0.7574 \\
0.7459\end{array}$ & $\begin{array}{l}0.3171-0.9964 \\
0.3208-0.9946\end{array}$ \\
\hline
\end{tabular}

$\cdot N=$ Number of trees: $n=$ Number of observations.

\section{Model Development}

In this study, the components of a stem in relation to its volume are as follows: stump volume below a given stump height, merchantable volume, and top volume. The first two components, when combined, make up the ground-to-limit volume. Thus, in ratio values, the total of ground-to-limit volume and the top volume is equal to 1 . Based on these facts, therefore, the main intention of this study has been, first, to develop a prediction equation for the ratio of ground-to-limit volume, and second, to establish a method of calculating the ratio of stump volume. Merchantable volume ratio or the merchantable volume conversion factor would then be obtained by subtracting stump volume ratio from this groundto-limit volume ratio. Afterwards, stem taper equations were derived from the ground-to-limit volume ratio equations.

From the definition of merchantable volume it will be seen that the merchantability can be expressed either by a diameter limit along the stem or by a height limit. In Canada it is the merchantable top diameter that is generally used (Bonnor 1978, Honer et al. 1983) to predict merchantable volume. However, merchantable height may also have a role in the estimation of this volume, although to a lesser degree. For this reason, in the development of the ratio equations both $\mathrm{d}$ and $\mathrm{h}$ are considered

The development of models for predicting ground-to-limit volume ratio is based on the following argument: when we examine the merchantable volume distribution in two trees of the same shape which are assumed to be proportionally similar in all dimensions, we see that for a given d/D ratio (or, $\mathrm{h} / \mathrm{H}$ ratio) there is only one merchantable volume/stem volume ratio (Figure 2). For these two trees the following ratio equations can be written:

$\frac{D E}{A B}=\frac{G H}{A F}=\frac{I_{1}}{H_{1}}=\frac{I_{1}}{H_{1}}$, and

$\frac{\text { area } \mathrm{DEC}}{\text { area } A B C}=\frac{\text { area } \mathrm{GHI}}{\text { area } A F I}$, or $\frac{\text { area } \mathrm{DABE}}{\text { area } A B C}=\frac{\text { area } \mathrm{GAFH}}{\text { area } A F I}$

Because these areas are proportional, the volumes to be created by their revolution around their vertical axes (Alemdag 1978) will also be proportional. This means, for a given $\mathrm{d} / \mathrm{D}$ or $\mathrm{h} / \mathrm{H}$ ratio, merchantable volume ratio does not change from tree to tree, regardless of tree size. Theoretically, $\mathrm{H}$ or $\mathrm{D}$ does not have any effect on merchantable volume ratio when it is expressed either by relative diameter or by relative height, respectively. This theorem was verified by plotting VL/ VT for all the data over d/D by three classes of $H$, and over $h$ / $\mathrm{H}$ by three classes of $\mathrm{D}$ (Figure 3 ) where no evidence of difference among these classes is apparent. Moreover, plotting the ratio of VL/VT by three d/D classes (class 1 is
0.076-0.375; class 2, 0.376-0.675; class $3,0.676-0.975)$ over form factor $f$, being an expression of stem form and the stem fullness, did not illustrate any trend of increase or decrease with changing $f$ (Figure 4). This further supports the above hypothesis. Within class 1 , the distribution of VL/VT constitutes a horizontal line. In the other two classes these $\mathrm{VL} / \mathrm{VT}$ values are all scattered, suggesting the possibility of horizontal lines with narrower $d / D$ classes. The above discussion leads to the concept of the constant form factor volume equation which has been in use in forestry for many years.

It is clearly noticeable from these plottings that the merchantable volume/total stem volume ratio forms a curve as a function of $d / D$, or $h / H$. While many polynomials can be written, there are two points that must be considered: (1) equations should be conditioned to yield VL/VT $=1$ when d/D is zero, or $\mathrm{h} / \mathrm{H}$ is 1 and, (2) equations should be formulated in such a way that the ground-to-limit volume/total stem volume ratio does not exceed 1 . With these constraints in mind several possible expressions were formulated and tested, and the six final models (three for $d / D$ and three for $h / H$

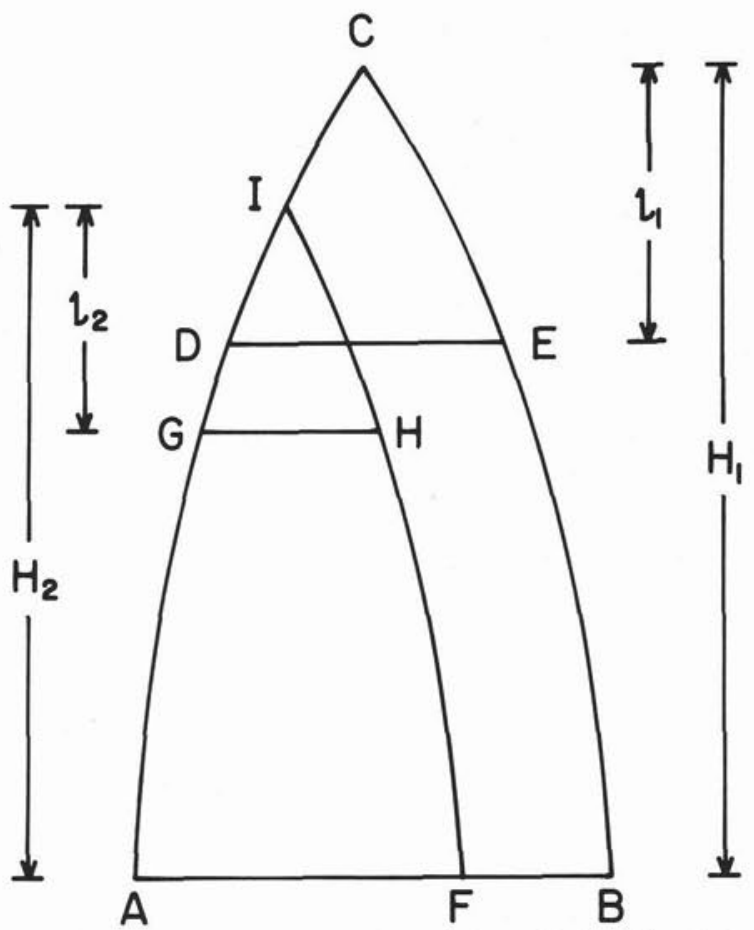

Figure 2. A schematic illustration of the relationships between diameters, areas, and volumes on similar trees. 


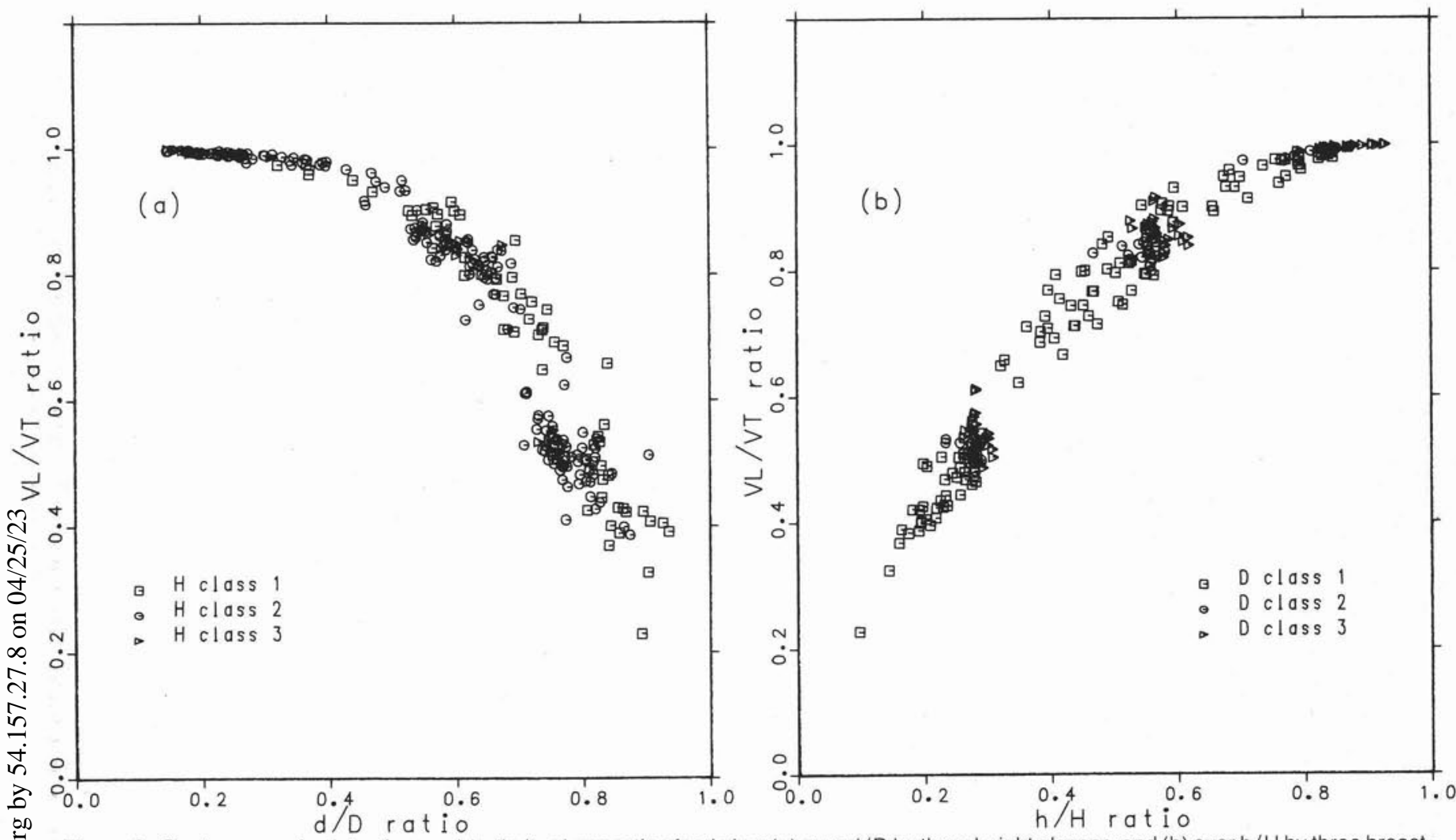

Figure 3. Scattergram of points of ground-to-limit volume ratio of red pine: (a) over $d / D$ by three height classes, and (b) over $h / H$ by three breast$\dot{\epsilon}$

expressions) as shown in Table 2 were chosen for further analyses. In order to solve Models 1, 2, 4 and 5 for their parameters, they were reconstructed for linear regression analyses. After this was done, a multiplicative error term was introduced to all six models of $d / D$ and $h / H$. The model used by Alemdag (1982) to predict merchantable biomass, in the form of

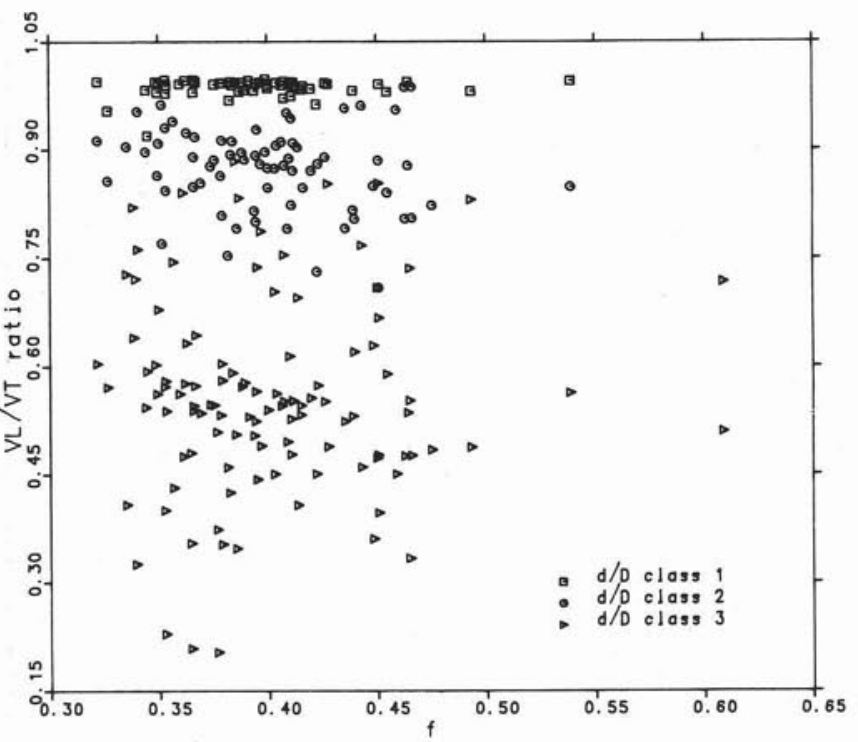

Figure 4. Distribution of ground-to-limit volume ratios of red pine over form factor by three $d / D$ classes, suggesting their independence of $f$ within each $d / D$ class.
Merchantable ratio $=b_{0}+b_{1} \cdot(d / D)+b_{2} \cdot(d / D)^{2}$

was not included with these models because of its failure to satisfy the second constraint. However, it must be noted that Model 1 (or Model 6) presented in this report is a modification of this original model in the following ways: first, it was conditioned to be 1 when $d / D$ is zero (or $h / H$ is 1 ), and second, it was conditioned not to go over 1 at any given d/D (or $\mathrm{h} / \mathrm{H}$ ) by removing the term of the first power. Following this, the quadratic power of the second term was allowed to take any value.

Furthermore, two other models were developed and tested for the prediction of ratio of stump volume at $0.30 \mathrm{~m}$ as a function of total stem volume, and of $\mathrm{D}^{2}$ and $\mathrm{H}$. These are also provided in Table 2.

\section{Analyses and Results}

In the following analyses, linear regression analysis techniques were used. For this purpose, the nonlinear leastsquares technique could also be employed (Payandeh 1983); however, the linear technique was preferred because of its simplicity. In evaluating the models to fit data, the fit index (FI) and the standard error of estimate as percent of the mean (SEE\%) were employed. Fit index is a statistical measure of precision that is similar to the multiple coefficient of determination $\left(\mathrm{R}^{2}\right)$ (Alemdag 1986). Analyses were based on the data summarized in Table 1 , after retaining an independent set of data for checking purposes. ${ }^{4}$

\footnotetext{
${ }^{4}$ The independent data set for checking purposes was arranged systematically after the initial observation was selected in a random way, by extracting every seventh observation from the whole data file (around 14\%) in which observations were recorded in rows, three for each tree. Taking every seventh observation provided an excellent system of rotating among the first, second and third observations which are from three different locations on the stem and third observations which are from three different locations on the stem, the data, was used for deriving the equations
} 
Table 2. Conditioned models tested for ratios of ground-to-limit volume and stump volume

\begin{tabular}{cl}
\hline Model No. & \multicolumn{1}{c}{ Model form } \\
\hline & (a) Models using $d / D$ as a variable \\
1 & $K=1+b_{1} \cdot(d / D) b_{2}$ \\
2 & $K=1+b_{1} \cdot\left(I n(d / D+1) b_{2}\right.$ \\
3 & $K=\exp \left(b_{1} \cdot(d / D) b_{2}\right)$ \\
& $(b)$ Models using h/H as a variable \\
4 & $K=1+b_{1} \cdot(1-h / H) b_{2}$ \\
5 & $K=1+b_{1} \cdot(0.693147-1 n(h / H+1))^{b_{2}}$ \\
6 & $K=\exp \left(b_{1} \cdot(1-h / H)^{2}\right)$ \\
& $(c)$ Stump models \\
7 & VS30/VT $=b_{0}+b_{1} \cdot V T+b_{2} \cdot V T 2$ \\
8 & VS30/VT $=b_{0}+b_{1} \cdot D^{2}+b_{2} \cdot H+b_{3} \cdot D 2 H$
\end{tabular}

\section{Model fit for merchantable ratio}

As will be seen in Table 2, none of the six models for the prediction of ground-to-limit volume ratio is linear. For this reason, to enable development of regression parameters, their transformations were used with the data. An example of these transformed models is given below using Model 1:

$\ln (K-1)=b_{0}+b_{2} \cdot \ln (d / D) ;$ where $b_{0}=\ln b_{1}$

After establishing the $b$ coefficients of these models for each species, the FI for the expression of goodness-of-fit and the SEE\% were calculated (Table 3). Note that the parameters of each model equation were used with the same data that were used in developing them. As will be seen, the fit of all models to the data is quite good, $\mathrm{Fl}$ being above 0.890 for red pine and 0.825 for sugar maple. It is also clear that fitting the models of $h / H$ is better than that of $d / D$. It was found that for both species, Model 1 as a function of $d / D$ and Model 6 as a function of $\mathrm{h} / \mathrm{H}$ gave the most accurate results. For these models the $\mathrm{FI}$ values for red pine are 0.907 and 0.976 , respectively, and 0.847 and 0.972 for sugar maple. Therefore, these two models were adopted for use in practice; their equation coefficients are given in Table 4. These merchantable prediction equations not only provide access to the merchantability ratios but also make it possible to study the distribution of volume over the tree stem by any given stem diameter or at any given height.

The behaviour of these two models in relation to $D, d, H$, and $\mathrm{h}$ is illustrated in Figure 5, using red pine equations as an example. It will be observed that these equations show logical

\begin{tabular}{|c|c|c|c|c|}
\hline \multirow{2}{*}{ Model No. } & \multicolumn{2}{|c|}{ Red pine } & \multicolumn{2}{|c|}{ Sugar maple } \\
\hline & FI & SEE $\%$ & FI & SEE $\%$ \\
\hline
\end{tabular}

(a) Ground-to-limit volume ratio as a function of $d / D$

$\begin{array}{lllll}1 & 0.907 & 8.36 & 0.847 & 11.09 \\ 2 & 0.895 & 8.89 & 0.827 & 11.78 \\ 3 & 0.902 & 8.59 & 0.839 & 11.37\end{array}$

(b) Ground-to-limit volume ratio as a function of $h / H$

\begin{tabular}{lllll}
4 & 0.967 & 5.01 & 0.954 & 6.09 \\
5 & 0.941 & 6.70 & 0.921 & 7.97 \\
6 & 0.976 & 4.26 & 0.972 & 4.71 \\
\hline
\end{tabular}

Table 4. Regression coefficients and statistics of Models 1 and 6

\begin{tabular}{|c|c|c|c|c|}
\hline \multirow{2}{*}{ Model No. } & \multicolumn{2}{|c|}{ Regression coefficients } & \multirow{2}{*}{ FI } & \multirow{2}{*}{ SEE $\%$} \\
\hline & $\mathbf{b}_{1}$ & $\mathbf{b}_{2}$ & & \\
\hline \multicolumn{5}{|c|}{ Red pine } \\
\hline $\begin{array}{l}1 \\
6\end{array}$ & $\begin{array}{l}-0.92826 \\
-1.558\end{array}$ & $\begin{array}{l}3.348 \\
2.748\end{array}$ & $\begin{array}{l}0.907 \\
0.976\end{array}$ & $\begin{array}{l}8.36 \\
4.26\end{array}$ \\
\hline \multicolumn{5}{|c|}{ Sugar maple } \\
\hline $\begin{array}{l}1 \\
6\end{array}$ & $\begin{array}{l}-0.72968 \\
-1.785\end{array}$ & $\begin{array}{l}2.840 \\
3.718\end{array}$ & $\begin{array}{l}0.847 \\
0.972\end{array}$ & $\begin{array}{r}11.09 \\
4.71\end{array}$ \\
\hline
\end{tabular}

and acceptable trends for a given value of any of these variables, indicating the appropriateness of the models. These curves also illustrate the volume distribution along the stem for any given breast height diameter, total tree height, diameter at various locations on the stem, and height to any point on the bole.

\section{Stump equations}

Models 7 and 8 (Table 2) were tested to fit the data for the prediction of stump volume ratio at $0.30 \mathrm{~m}$ stump height. It was found that for sugar maple there was no correlation either between VS30/VT and total stem volume or between VS30/ $V T$ and $D^{2}$ and $H$, as the multiple coefficients of determination for both models were zero. For red pine these correlations were also very weak, with an $\mathrm{R}^{2}$ of 0.380 for Model 7 and 0.504 for Model 8 , and SEE \% values $30.3 \%$ and $25.7 \%$, respectively. This situation suggested that the arithmetic mean values of VS30/VT for these species can be used as reliably as any prediction equation and, as a result, these mean values are given in Table 5 for further uses.

It is obvious that not all trees will be cut at $0.30 \mathrm{~m}$ stump height in practice. Some stumps may be lower or higher than this, and therefore, will contain a different volume. This volume at different heights of stump was expressed as a ratio of the volume at $0.30 \mathrm{~m}$ stump height, using a generalized stump diameter/breast height diameter relationsip for both species (Alemdag and Honer 1977) and following a geometrical method in which the stump was assumed to be the frustum of a neiloid (Alemdag 1978). These ratios were then regressed over various stump heights by employing the following model:

$$
p=a_{1} \cdot h s+a_{2} \cdot h s^{2}
$$

where $p$ is the ratio of stump volume at a given stump height to stump volume at $0.30 \mathrm{~m}$ stump height, and where $\mathrm{p}$ equals zero when hs is zero. It is also conditioned to be 1 when hs is 0.30 ; thus $a_{2}=(1 / 0.09)-a_{1} \cdot(0.30 / 0.09)$ is written. After solution of the conditioned equation for $a_{1}$ by regression analysis, it was found to be 3.610 , and $\mathrm{a}_{2}$ was calculated as -0.922 . Equation 5 with these coefficients will be used for both species for converting stump volume ratio of $0.30 \mathrm{~m}$ to stump volume ratio at any other stump height, as in the form:

$$
\mathrm{VS} / \mathrm{VT}=(\mathrm{VS} 30 / \mathrm{VT}) \cdot \mathrm{p}
$$

\section{Merchantable volume conversion factor}

As mentioned earlier, total stem volume is made up of ground-to-limit volume and top volume, and ground-to-limit volume consists of merchantable volume and stump volume. Furthermore, stump volume is a proportion of stump volume at $0.30 \mathrm{~m}$ stump height. Thus, for merchantable volume we can write: 

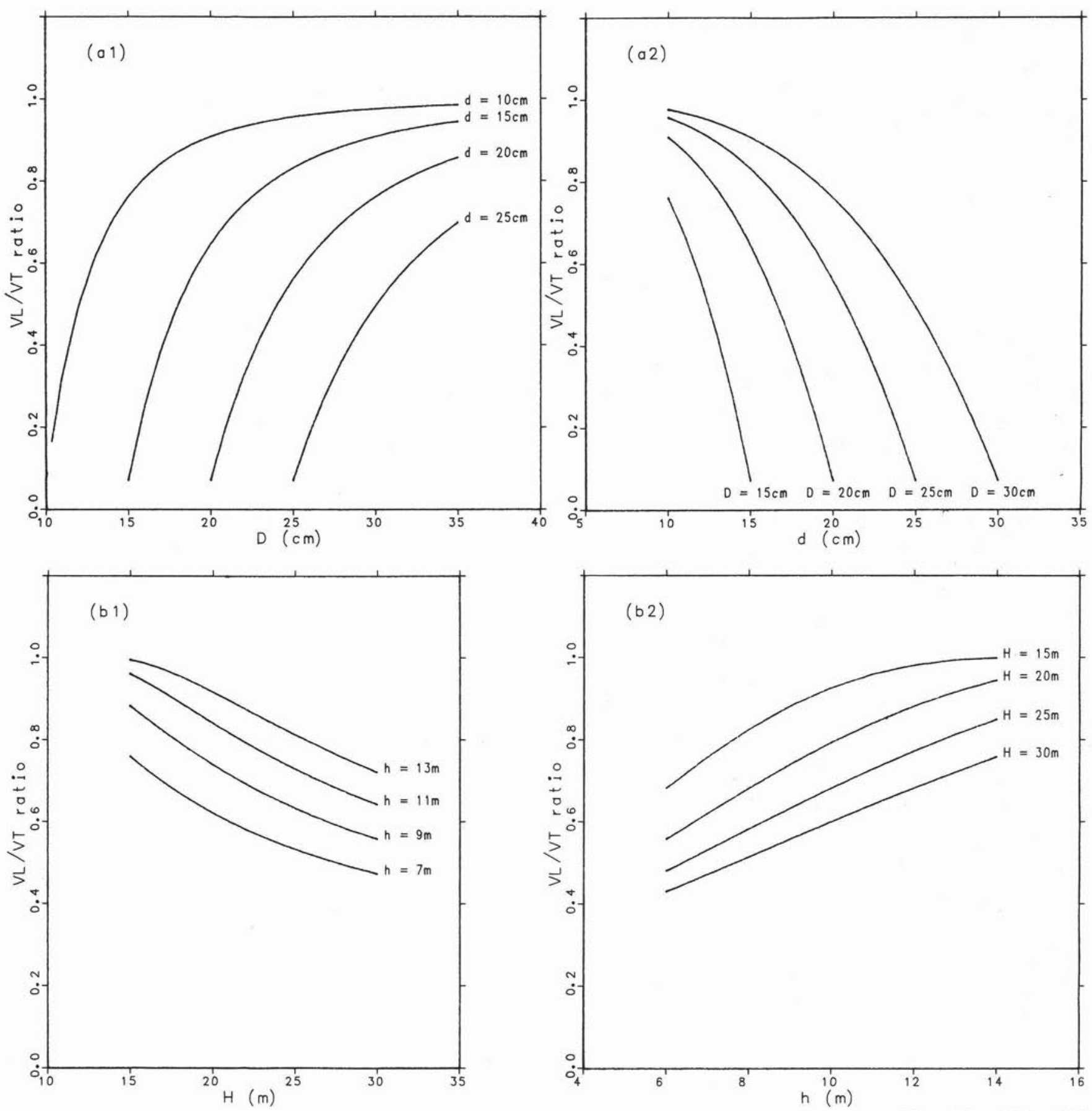

Figure 5. Behaviour of the red pine ground-to-limit volume ratio equations: (a1 and a2) Model 1 for some given values of $D$ and d, and (b1 and b2) Model 6 for some given values of $\mathrm{H}$ and $\mathrm{h}$.

$$
\begin{aligned}
& V M=V L-V S \\
& V M=V L-V S 30 \cdot p
\end{aligned}
$$

and in terms of ratios of total stem volume:

$$
\mathrm{VM} / \mathrm{VT}=\mathrm{K}-(\mathrm{VS} 30 / \mathrm{VT}) \cdot \mathrm{p}
$$

This is the merchantable volume conversion factor. Consequently, the top volume ratio is:

$$
\mathrm{VP} / \mathrm{VT}=1-\mathrm{K}
$$

Because, in this report, the volumes of all components are expressed as ratios of the total stem volume, the estimation of the merchantable volume of a stem to a given d or $\mathrm{h}$ will be done using:

$$
V M=[K-(V S 30 / V T) \cdot p] \cdot V T
$$

In this formula the first multiplier is the merchantable volume conversion factor which is made up of already developed ratios. The second multiplier, the total stem volume, can be expressed in any unit and of any function in practice. Similarly, ground-to-limit volume and top volume are as follows:

$$
V L=K \cdot V T
$$


Table 5. Statistics of stump volume ratio at $0.30 \mathrm{~m}$ stump height

\begin{tabular}{lrcccc}
\hline \multirow{2}{*}{ Species } & & \multicolumn{4}{c}{ VS30/VT } \\
\cline { 3 - 6 } & $\mathbf{N}^{*}$ & Mean & Range & SD $\dagger$ & SE $\dagger$ \\
\hline Red pine & 102 & 0.0476 & $0.0035-0.0976$ & 0.0173 & 0.0011 \\
Sugar maple & 93 & 0.0554 & $0.0024-0.0857$ & 0.0149 & 0.0010 \\
\hline
\end{tabular}

- Number of trees

$+\mathrm{SD}=$ Standard deviation: $\mathrm{SE}=$ Standard error of mean

$$
V P=(1-K) \cdot V T
$$

\section{Estimated values versus observed values}

After the ground-to-limit volume ratio equations of Models 1 and 6 for both species were developed using the main set of data, their performances for accuracy and precision were tested. For this purpose the independent set of data which was described previously was employed (Table 1). It will be seen that there is a great similarity between this data set and the one used in developing the equations.

First, by using each equation with its own coefficients and with the observed checking data, the estimated values of the ground-to-limit volume ratio were calculated for each observation. These estimated values were then plotted against observed values of the ground-to-limit volume ratio, using the same scale, in order to inspect visually how well they conformed to a $45^{\circ}$ line. It was found that the deviations from this line are within a reasonable range for both models of both species. As an example, the plottings of the $d / D$ and $h / H$ models of red pine are provided (Figure 6). Secondly, the differences of estimated value minus observed value were calculated and their means (biases), standard deviations, and ranges were computed with and without the classes $d / D$ and $\mathrm{h} / \mathrm{H}$. The overall mean bias was found to be only +0.0187 for red pine and +0.0407 for sugar maple when the estimates were made by the $d / D$ equations, and +0.0053 and +0.0014 by the $\mathrm{h} / \mathrm{H}$ equations, with small standard deviations. These mean biases are acceptable. Only the residuals by classes showed an overestimation as high as +0.0821 ; this was in the highest $d / D$ class of sugar maple. These checking results revealed that the suggested models are sufficiently accurate and precise to be used confidently in practice.

\section{Taper equations}

Once these two models for each species are developed for the estimates of the ground-to-limit volume ratio, one by d/ $\mathrm{D}$ (Model 1) and one by $\mathrm{h} / \mathrm{H}$ (Model 6), they can be easily transformed into taper equations. Following the same argument presented earlier in this report for model development, for any given tree at any point on the stem, VL/ VT by $d / D$ will be equal to VL/VT by $h / H$. Thus we can write:

$$
1+b_{1} \cdot(d / D)^{b_{2}}=\exp \left(c_{1} \cdot(1-h / H)^{c_{2}}\right)
$$

where $b_{1}$ and $b_{2}$ parameters are from the $d / D$ model (Table 4 ), and $c_{1}$ and $c_{2}$ are the replacements, respectively, for $b_{1}$ and $b_{2}$ of the $\mathrm{h} / \mathrm{H}$ model (Table 4). Then, after rearranging this equation, we will have the following taper curve equation:

$d=D \cdot\left[\frac{\exp \left(c_{1} \cdot(1-h / H)^{C_{2}}\right)-1}{b_{1}}\right]^{1 / b_{2}}$

A similar expression for height to any top diameter could be derived from Equation 14 as follows:

$h=H \cdot\left[1-\left(\frac{\ln \left(1+b_{1} \cdot(d / D)_{2}\right)}{c_{1}}\right) 1 / c_{2}\right]$

It must be noted that because these taper equations were not developed independently by regression analysis but were derived from the merchantable ratio equations, and because they were not conditioned for the breast height diameter, some anomalous predictions of $d$ and $h$ may be expected at the lower and the higher parts of the stem.
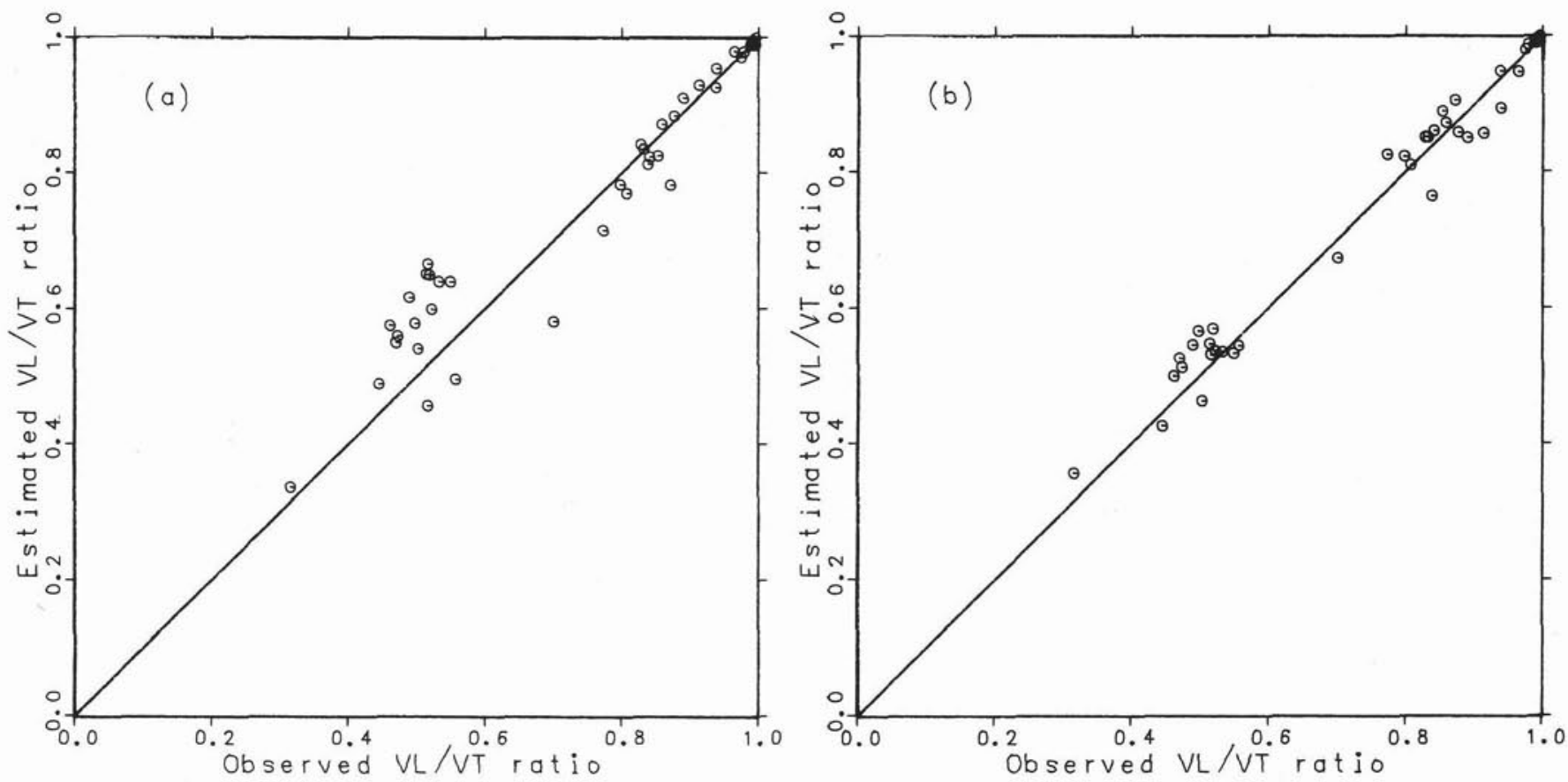

Figure 6. An illustration of relationships between estimated and observed values of ground-to-limit volume ratios for red pine based on (a) Model 1. and (b) Model 6. Data used were separate from the data employed in developing the equations. 
Table 6. An example of the estimated volume ratios of different components by various stump heights using Models 1 and 6 of red pine

\begin{tabular}{|c|c|c|c|c|c|c|c|}
\hline \multirow[t]{2}{*}{$d / D$} & \multirow[t]{2}{*}{$h / H$} & \multirow[t]{2}{*}{ Stump height $(\mathrm{m})$} & \multirow[t]{2}{*}{$\begin{array}{c}\text { Ground-to-limit } \\
\text { volume }\end{array}$} & \multirow{2}{*}{\multicolumn{2}{|c|}{$\begin{array}{c}\text { Top volume Stump volume } \\
\text { as ratio of total stem volume }\end{array}$}} & \multirow[t]{2}{*}{$\begin{array}{l}\text { Merchantable } \\
\text { volume }\end{array}$} & \multirow[t]{2}{*}{ Total volume ${ }^{*}$} \\
\hline & & & & & & & \\
\hline 0.40 & & $\begin{array}{l}0.10 \\
0.20 \\
0.30 \\
0.40\end{array}$ & $\begin{array}{l}0.9568 \\
0.9568 \\
0.9568 \\
0.9568\end{array}$ & $\begin{array}{l}0.0432 \\
0.0432 \\
0.0432 \\
0.0432\end{array}$ & $\begin{array}{l}0.0167 \\
0.0326 \\
0.0476 \\
0.0617\end{array}$ & $\begin{array}{l}0.9401 \\
0.9242 \\
0.9092 \\
0.8951\end{array}$ & $\begin{array}{l}1.0 \\
1.0 \\
1.0 \\
1.0\end{array}$ \\
\hline & 0.65 & $\begin{array}{l}0.10 \\
0.20 \\
0.30 \\
0.40\end{array}$ & $\begin{array}{l}0.9166 \\
0.9166 \\
0.9166 \\
0.9166\end{array}$ & $\begin{array}{l}0.0834 \\
0.0834 \\
0.0834 \\
0.0834\end{array}$ & $\begin{array}{l}0.0167 \\
0.0326 \\
0.0476 \\
0.0617\end{array}$ & $\begin{array}{l}0.8999 \\
0.8840 \\
0.8690 \\
0.8549\end{array}$ & $\begin{array}{l}1.0 \\
1.0 \\
1.0 \\
1.0\end{array}$ \\
\hline
\end{tabular}

-Either ground-to-limit volume plus top volume, or, top volume plus stump volume plus merchantable volume.

Consequently, stem volumes can be computed from these taper equations by taking their integrals.

\section{Application}

A practical application for estimating merchantable volume ratios and stem taper is described below.

For merchantability, the two equations for red pine were used and the ratios of ground-to-limit volume, top volume, stump volume, and merchantable volume calculated. These calculations were made for $d / D=0.40$ and $h / H=0.65$ for different stump heights using the equation of Model 1 (or Model 6 for $\mathrm{h} / \mathrm{H}$ ), Equation 10, Equation 6, and Equation 9. The estimated values are presented in Table 6

It is possible to simplify the equations of Model 1. If, for instance, $d=7.0 \mathrm{~cm}$, as is the case in Ontario now, then the ground-to-limit volume ratio formulas for red pine and sugar maple become only an expression of the breast height diameter and, respectively, change to the following forms:

$$
\begin{aligned}
& K=1-626.697 \cdot(1 / D)^{3.348} \\
& K=1-183.320 \cdot(1 / D)^{2.840}
\end{aligned}
$$

For taper equations, when working with red pine, Equation 15 results in $12.9 \mathrm{~cm}$ if an upper diameter is looked for at a height of $14.50 \mathrm{~m}$ on a stem $\mathrm{D}=25.0 \mathrm{~cm}$ and $\mathrm{H}=23.30 \mathrm{~m}$; and Equation 16 produces $16.93 \mathrm{~m}$ if a height is searched for at an upper diameter of $10.0 \mathrm{~cm}$ on the same stem.

\section{Summary}

One method of estimating the merchantable volume of a stem is the ratio method. In the present paper this ratio is expressed as the ground-to-limit volume to total stem volume (VL/VT), both volumes being inside bark. This ratio of groundto-limit volume is strongly correlated with the ratio of merchantable top diameter/breast height diameter (d/D) or merchantable height/total tree height $(h / H)$, regardless of tree size; there is only one VL/VT for a given ratio of $d / D$ or $h /$ $\mathrm{H}$. Merchantable top diameter is flexible in these expressions since $d / D$ varies from zero to 1 for any given $D$. The same is also true for the $\mathrm{h} / \mathrm{H}$ variable.

Model 1 was best for estimating the ratio of ground-tolimit volume by $d / D$ for red pine and sugar maple as evaluated by the statistical measures of $\mathrm{FI}$ and SEE\%. Similarly, Model 6 was best when the variable $\mathrm{h} / \mathrm{H}$ was used. When tested by an independent set of checking data, equations of these models performed well. The overall bias for red pine and sugar maple were +0.0187 and +0.0407 respectively, when $d / D$ equations are employed; and +0.0053 and +0.0014 when $\mathrm{h} / \mathrm{H}$ equations are used.

These models estimate ground-to-limit volume ratio (VL/ VT). To arrive at the ratio of merchantable volume (VM/VT), the ratio of stump volume for a given stump height (VS/VT) must be deducted. The merchantable volume in its actual amount would be the product of this VM/VT or the merchantable volume conversion factor and the total stem volume (VT) of any unit of measurement. These ratio equations can also provide estimates of volume distribution within the stem for various diameters or heights.

Constructing ground-to-limit volume ratio equations led to developing stem taper equations. Taper equations were derived from these equations for predicting (a) any diameter on the stem at a given height, and (b) any height along the stem at a given diameter, both based on $\mathrm{D}$ and $\mathrm{H}$.

These various ratios can easily be integrated into any existing system where merchantable volume is being estimated, or where electronic field data collectors interfaced with a computer are used.

\section{Acknowledgments}

The author acknowledges the assistance of Mrs. L.R. Roy of PNFI in running the computer analyses. He also thanks the paper's reviewers for helpful suggestions.

\section{References}

Alemdag, I.S. 1978. An analytical look at the log volume formulas. Environ. Can., Can. For. Serv., For. Manage. Inst.

Alemdag, I.S. 1982. Biomass of the merchantable and unmerchantable portions of the stem. Environ. Can., Can. For. Serv., Petawawa Natl. For. Inst., Inf. Rep. PI-X-20.

Alemdag, I.S. 1983. Formulation of the form-class taper curves. Environ. Can., Can. For. Serv., Petawawa Natl. For. Inst., Inf. Rep. PI-X-22

Alemdag, I.S. 1986. Estimating ovendry mass of trembling aspen and white birch using measurements from aerial photographs. Can. J. For. Res. 16: 163-165.

Alemdag, I.S. and T.G. Honer. 1977. Metric relationships between breast-height and stump diameter for eleven tree species from eastern and central Canada. Environ. Can., Can. For. Serv., For Manage. Inst., Inf. Rep. FMR-X-49M.

Amidon, E.L. 1984. A general taper functional form to predict bole volume for five mixed-conifer species in California. For. Sci. 30 : 166-171

Anonymous. 1930. Form-class volume tables. Can. Dept. Interior, For. Serv.

Behre, C.E. 1923. Preliminary notes on studies of tree form. J. For. 21: 507-511. 
Behre, C.E. 1927. Form-class taper tables and volume tables and their application. J. Agr. Res. 35: 673-744

Bennett, F.A., C.E. McGee and J.L. Clutter. 1959. Yield of old-field slash pine plantations. USDA For. Serv., SE For. Exp. Sta. Paper No. 107

Bennett, F.A. and B.F. Swindel. 1972. Taper curves for planted slash pine. USDA For. Serv. Res. Note SE-179.

Biging, G.S. 1984. Taper equations for second-growth mixed conifers of northern California. For. Sci. 30: 1103-1117.

Bonnor, G.M. (ed.). 1978. A guide to Canadian forest inventory terminology and usage. Environ. Can., Can. For. Serv., For Manage. Inst.

Brister, G.H., J.L. Clutter and T.M. Skinner. 1980. Tree volume and taper functions for site-prepared plantations of slash pine. Southern J. Appl. For. 4: 139-142.

Bruce, D., R.O. Curtis and C. Vancoevering. 1968. Development of a system of taper and volume tables for red alder. For. Sci. 14 339-350.

Burkhart, H.E. 1977. Cubic-foot volume of loblolly pine to any merchantable top limit. Southern J. Appl. For. 1: 7-9

Cao, Q.V., and H.E. Burkhart. 1980. Cubic-foot volume of loblolly pine to any height limit. Southern J. Appl. For. 4: 166-168.

Cao, Q.V., H.E. Burkhart, and T.A. Max. 1980. Evaluation of two methods for cubic-volume prediction of loblolly pine to any merchantable limit. For. Sci. 26: 71-80

Clutter, J.L. 1980. Development of taper functions from variable-top merchantable volume equations. For. Sci. 6: 117-120.

Demaerschalk, J.P. 1972. Converting volume equations to compatible taper equations. For. Sci. 18: 241-245.

Demaerschalk, J.P. 1973. Integrated systems for the estimation of tree taper and volume. Can. J. For. Res. 3: 90-94

Demaerschalk, J.P. and A. Kozak. 1977. The whole-bole system: a conditional dual-equation system for precise prediction of tree profiles. Can. J. For. Res. 7: 488-497

Gingrich, S.F. 1962. Adjusting shortleaf pine volume tables for different limits of top utilization. USDA For. Serv., Cent. States For. Exp. Sta., Tech. Pap. 190

Goulding, C.J. and J.C. Murray. 1976. Polynomial taper equations that are compatible with tree volume equations. N.Z. J. For. Sci. 5: 313-322

Green, E.J. and D.D. Reed. 1985. Compatible tree volume and taper functions for pitch pine. North. J. Appl. For. 2(1):14-16.

Honer, T.G. 1964. The use of height and squared diameter ratios for the estimation of merchantable cubic foot volume. For. Chron. 40: $324-331$
Honer, T.G. 1965. Volume distribution in individual trees. Woodland Review, Pulp and Paper Mag. Can. 499-508.

Honer, T.G., M.F. Ker and I.S. Alemdag. 1983. Metric timber tables for the commercial tree species of central and eastern Canada. Environ. Can., Can. For. Serv., Maritimes For. Res. Centre, Inf. Rep. $\mathrm{M}-\mathrm{X}-140$

James, C.A. and A. Kozak. 1984. Fitting taper equations from standing trees. For. Chron. 60: 157-161.

Kozak, A., D.D. Munro and J.H.G. Smith. 1969. Taper functions and their application in forest inventory. For. Chron. 65: 278-283.

Liu, C.J. 1980. Log volume estimation with spline approximation. For. Sci. 26: $361-369$

Liu, C.J. and T.D. Keister. 1978. Southern pine stem form defined through principal component analysis. Can. J. Forest Res. 8: 188197

Matney, T.G. and A.D. Sullivan. 1982. Variable top volume and height predictors for slash pine trees. For. Sci. 28: 274-282.

Monserud, R.A. 1981. Estimating truncated tree volumes with the Behre hyperboloid and existing total volume equations. For. Sci. 27: 253265

Ormerod, D.W. 1973. A simple bole model. For. Chron. 49: 136-138.

Payandeh, B. 1983. Some applications of nonlinear regression models in forestry research. For. Chron. 59: 244-248

Reed, D.D. and J.C. Byrne. 1985. A simple, variable form volume estimation system. For Chron. 61: 87-90

Reed, D.D. and E.J. Green. 1984. Compatible stem taper and volume ratio equations. For. Sci. 30: 977-990.

Romancier, R.M. 1961. Weight and volume of plantation-grown loblolly pine. USDA Forest Serv., SE For. Exp. Sta. Res. Note 161

Schlaegel, B.E. 1981. Willow oak volume and weight tables for the Mississippi delta. USDA Forest Serv., Southern For. Exp. Sta. Res. Paper SO-173

Stiell, W.M. and F.W. von Althen. 1964. Revised taper curves and volume tables for plantation red pine. Can. Dept. For., For. Res. Branch Pub. No. 1075

Van Deusen, P.C., A.D. Sullivan and T.G. Matney. 1981. A prediction system for cubic foot volume of loblolly pine applicable through much of its range. Southern J. Appl. For. 5: 186-189.

Van Deusen, P.C., T.G. Matney and A.D. Sullivan. 1982. A compatible system for predicting the volume and diameter of sweetgum trees to any height. Southern J. Appl. For. 6: 159-163.

\section{The Annual Meeting Schedule \\ 1988 - September 19-22, Prince Albert, Sask. Theme: Forest Management: A Shared Responsibility \\ - Aménagement forestier: une responsibilité partagée \\ 1989 - October 16-20, Kananaskis Country, Alta. Theme: Reconciling Vision with Reality \\ - Réconcilier la vision et la réalité \\ 1990 - August 20-24, Fredericton, N.B. \\ 1991 - September 29-October 4, Toronto, Ontario}

\section{Errata}

We apologize to Mr. Claude Lebel of Longueuil, Quebec for misspelling both his name and his home town in our October issue announcement that he was a winner of the $\mathrm{J}$. Miles Gibson Forestry Award at the UNB 1987 Fall Convocation. 